Review

\title{
Cytotoxic Terpene Quinones from Marine Sponges
}

\author{
Marina Gordaliza \\ Department of Pharmaceutical Chemistry, Pharmacy Faculty, Salamanca University, Campus Miguel \\ de Unamuno, 37007 Salamanca, Spain; E-Mail: mliza@usal.es; Tel.: +34-923-294-528; \\ Fax: +34-923-294-515
}

Received: 7 October 2010; in revised form: 12 November 2010 / Accepted: 17 November 2010 / Published: 24 November 2010

\begin{abstract}
The 1,4-benzoquinone moiety is a common structural feature in a large number of compounds that have received considerable attention owing to their broad spectrum of biological activities. The cytotoxic and antiproliferative properties of many natural sesquiterpene quinones and hydroquinones from sponges of the order Dictyoceratida, such as avarol, avarone, illimaquinone, nakijiquinone and bolinaquinone, offer promising opportunities for the development of new antitumor agents. The present review summarizes the structure and cytotoxicity of natural terpenequinones/hydroquinones and their bioactive analogues and derivatives.
\end{abstract}

Keywords: terpene quinone; terpene hydroquinone; avarone; avarol; cytotoxicity

\section{Introduction}

The few therapeutic novelties of synthetic origin that have appeared on the pharmaceutical market, of which more than $88 \%$ are based on preexisting structures, have flooded the pharmaceutical world with very similar products. This has led to a new and enthusiastic retrospective appraisal of the active principles of the molecules integrating medicinal plants and different natural sources. It is for these reasons that research on natural compounds has aroused considerable interest at the academic, commercial and governmental levels.

Of the different natural sources, the sea has become an important basis for the collection of natural compounds of use to humans and it is clear that this will continue to be the case in the future [1-13]. Interest in marine organisms, both animals and plants, as sources of active substances was boosted at the beginning of the seventies by the work of several marine research teams: Universities of Hawaii and Oklahoma and The Scripps Institution of Oceanography in California, as well as other teams in Japan and Europe. This began with the isolation of prostaglandins from corals, followed by the 
discovery of other derivatives. In recent years, it has been possible to isolate and characterize thousands of compounds, many of which exert important activities in several biological systems [14].

The discovery of drugs from marine natural products has enjoyed a renaissance in the past few years [15-19]. Ziconotide (Prialt ${ }^{\circledR}$; Elan Pharmaceuticals), a peptide originally discovered in a tropical cone snail, was the first marine-derived compound to be approved in the United States in December 2004 for the treatment of pain [20]. Then, in October 2007, trabectedin (Yondelis ${ }^{\circledR}$; PharmaMar) became the first marine anticancer drug to be approved in the European Union [21]. In a recent congress held by the American Society of Oncology (Chicago, June 2010), attention was drawn to the antitumor properties of eribulin mesylate (E7389), designed by the Japanese laboratory Eisai (Eisai Research Institute, Andover, MA, USA) for the treatment of breast cancer. This is a synthetic analogue of the natural product halichondrin B, isolated from Halichondria okadai (Lissodendoryx sp.), a marine sponge commonly found in Japanese seas; its antitumor activity was discovered in 1986. Eribulin binds to the vinca domain of tubulin and inhibits the polymerization of tubulin and the assembly of microtubules, resulting in the inhibition of mitotic spindle assembly, the induction of cell cycle arrest at G2/M, and, potentially, tumor regression. Eribulin mesylate is now in phase II clinical trials and is active in metastatic or locally advanced breast cancer [22,23].

In particular, the cytotoxic and antiproliferative properties of many natural sesquiterpene quinones and hydroquinones from sponges of the order Dictyoceratida [24] such as avarol, avarone, illimaquinone, nakijiquinone and bolinaquinone offer promising opportunities for the development of new antitumor agents $[25,26]$. This has sparked interest in the chemical composition and cytotoxicity of a large number of marine species that contain metabolites with hybrid structures between terpenes and quinones/hydroquinones. Related to such terpenequinone structures, several studies have been published addressing the chemistry, activity and mechanisms of action of the compounds [27-33].

The present review addresses the terpenylquinones of marine origin with cytotoxic properties that are active against different tumor cell lines. It also deals with the cytotoxic hydroquinones and some semisynthetic analogues of bioactive terpenequinones. The compounds described herein are mainly natural sesquiterpenes and share a decalin structure, bound via a $1 \mathrm{C}$ carbon chain to a ring of differently functionalized $p$-benzoquinone or hydroquinone. Cytotoxic terpenequinone/hydroquinones are usually metabolites that incorporate a bicyclic sesquiterpene unit coupled to a quinone or quinol. Most of these possess a drimane or rearranged drimane skeleton. In the present work they have been grouped on the basis of the structural resemblance of the bicyclic moiety with some diterpene skeletons.

\section{Terpenylquinones with a Clerodane-Type Decalin Ring}

From extracts of sponges from the family Spongiidae, collected in Okinawa, it has been possible to isolate several compounds with an amino acid moiety on the benzoquinone ring: nakijiquinones $\mathrm{A}(\mathbf{1})$, B (2), C (3) and D (4) [34-36], or with a benzoxazol moiety: nakijinol (5) (Figure 1). It should be noted that the presence of aminoquinone compounds is not very common in natural products, these substances being the first examples of sesquiterpenequinones of natural origin with an amino acid or heterocyclic moiety. Nakijiquinones A (1), B (2), C (3) and D (4) showed in vitro cytotoxicity against $\mathrm{L}-1210$ ( $\mathrm{IC}_{50}$ values between 2.8 and $8.1 \mu \mathrm{g} / \mathrm{mL}$ ) and $\mathrm{KB}$ ( $\mathrm{IC}_{50}$ values between 1.2 and $7.6 \mu \mathrm{g} / \mathrm{mL}$ ). 
Figure 1. Nakijiquinones.

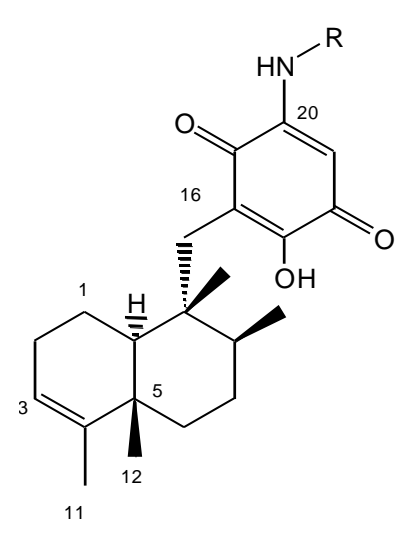

$$
\mathrm{R}=3 \mathrm{COOH}_{\mathrm{CO}} \text { nakijiquinone } \mathrm{A}
$$
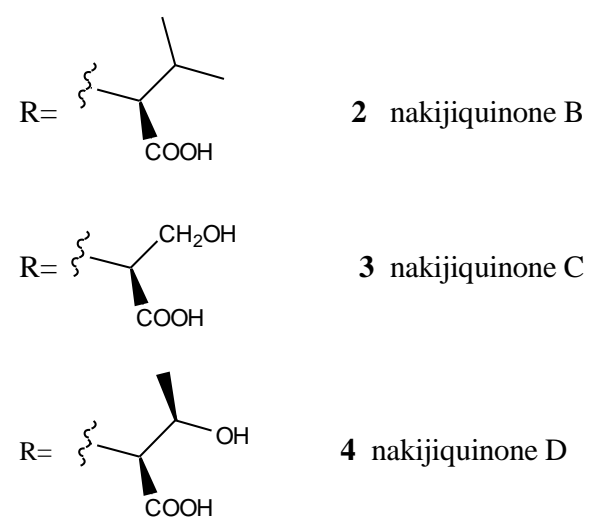

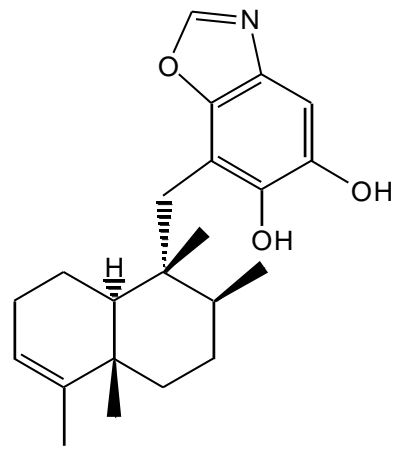

5 nakijinol<smiles>[Z2]c1c(O)c(C[C@@]2(C)[C@@H]3CCCC(=[V])[C@@]3(C)CC[C@H]2O)cc(C(C)=O)c1O</smiles>

$\mathrm{R}:$<smiles>CCCCc1cnc[nH]1</smiles>

8 nakijiquinone $\mathrm{G}$<smiles>[Y]CCCCNC(=N)N</smiles>

10 nakijiquinone I<smiles>[R]NC1=CC(=O)C(O)=C(C[C@@]2(C)[C@H](O)CC[C@@H]3[C@@H](C)CCC[C@]32C)C1=O</smiles>

$\mathrm{R}$ :<smiles>[Y6]CCc1ccccc1CC[Y6]</smiles>

$\mathrm{R}:$<smiles>CCC(C)CC</smiles>

11 nakijiquinone $\mathrm{K}$

12 nakijiquinone $\mathrm{L}\left(\Delta^{4(11)}\right)$<smiles>[Y]CCC(C)C</smiles>

13 nakijiquinone $\mathrm{N}$<smiles>CCC(C)CC</smiles>

14 nakijiquinone $\mathrm{O}$<smiles>CCCc1ccccc1</smiles>

15 nakijiquinone Q<smiles>C[Y4](=O)CC[AsH](=O)O</smiles>

16 nakijiquinone $\mathrm{R}$
17 nakijiquinone J

18 nakijiquinone $\mathrm{M}$

19 nakijiquinone $\mathrm{P}$

The new dimeric sesquiterpenoid quinones nakijiquinones $\mathrm{E}(\mathbf{6})$ and $\mathrm{F}(\mathbf{7})$ were isolated from an Okinawan marine sponge [37]. These nakijiquinones were the first dimeric sesquiterpenoid quinones possessing a 3-aminobenzoate moiety. Nakijiquinones G-I (8-10), containing a different amino group 
derived from amino acids, were isolated from Okinawan marine sponges of the family Spongiidae, and showed modest cytotoxicity and inhibitory activity against HER2 kinase, while nakijiquinone H (9) exhibited antimicrobial activity [38].

Nakijiquinones $\mathrm{J}-\mathrm{R}(\mathbf{1 7}, \mathbf{1 1}, \mathbf{1 2}, \mathbf{1 8}, \mathbf{1 3}, 14,19$ and 16), at $1 \mathrm{mM}$ were tested for inhibitory activities against EGFR and HER2 tyrosine kinases. Among them, nakijiquinones P (19) and R (16) exhibited inhibitory activities against EGFR (76 and >99\% inhibition, respectively), while nakijiquinones $\mathrm{N}(\mathbf{1 3}), \mathrm{O}(\mathbf{1 4})$ and R (16) showed inhibitory activities against HER2 (66\%, 59\% and 52\% inhibition, respectively) [39]. The HER2/Neu tyrosine kinase receptor is hugely overexpressed in about $30 \%$ of primary breast, ovary, and gastric carcinomas. Nakijiquinones are the only naturally occurring inhibitors of this important oncogene, and structural analogues of nakijiquinones may display inhibitory properties against other tyrosine kinase receptors involved in cell signaling and proliferation [40].

Another type of compound with bioactive properties includes those whose benzo(hydro)quinone ring is substituted by a methoxycarbonyl group, as is the case of polyfibrospongols and smenospondiol. Extracts of the marine sponge Polyfibrospongia australis, collected in Taiwan, were used to isolate polyfibrospongols A (20) and B (21) (Figure 2) [41], compounds showing cytotoxic activity against different tumor lines. From the South China sponge Dysidea arenaria, a new sesquiterpenoid hydroquinone, 19-hydroxy-polyfibrospongol B (22), was isolated, along with polyfibrospongol B (21) and other known terpenequinones [42].

Also showing cytotoxic, as well as antibacterial, activity is smenospondiol (23), isolated from dichloromethane extracts of several species of the genus Smenospongia and with a very similar structure $[43,44]$. This compound has also been called dictyoceratin A by other authors [45]. These compounds showed interesting levels of cytotoxicity when assayed against the P-388 (mouse lymphoma), KB-16 (human nasopharyngeal carcinoma) and A-549 (human lung carcinoma) cells, their $\mathrm{CI}_{50}$ values lying between 0.6 and $2.0 \mu \mathrm{g} / \mathrm{mL}$.

5-epi-Ilimaquinone (24) showed cytotoxic activity ( $\left.\mathrm{IC}_{50}\right)$ against P-388 leukemia cells $(2.2 \mu \mathrm{g} / \mathrm{mL})$ and different solid tumors: A-549 $(0.9 \mu \mathrm{g} / \mathrm{mL})$, HT-29 $(3.4 \mu \mathrm{g} / \mathrm{mL})$ and B16/F10 $(1.1 \mu \mathrm{g} / \mathrm{mL})[46]$. It has been suggested that ilimaquinone (25) induces a concentration-dependent antiproliferative effect in several types of cancer cell lines, including PC-3 and LNCaP prostate cancer, A549 non-small cell lung cancer and Hep3B hepatocellular carcinoma cells. The anticancer mechanism of ilimaquinone in the representative PC-3 cells was identified. Ilimaquinone (25) induced a time-dependent increase in G1 phase arrest and a subsequent increase in the hypodiploid sub-G1 phase (apoptosis) of the cell cycle. The cell cycle arrest was associated with a sustained high level of nuclear cyclin E but the absence of DNA synthesis, according to flow cytometric analysis, indicated an incomplete S phase. Although ilimaquinone-induced Golgi vesiculation, the data showed that the inhibition of cancer cell growth did not occur through Golgi fragmentation. Ilimaquinone did not activate extracellular signal-regulated kinase and phosphatidylinositol 3-kinase but induced an up-regulation, nuclear translocation and gene 153-induced DNA damage (CHOP/GADD153). Furthermore, the ilimaquinone-mediated antiproliferative effect was significantly reduced in antisense CHOP/GADD153-overexpressing cells. Ilimaquinone (25) also inhibited the DNA binding of NF- $\kappa$ B; however, this inhibitory effect cannot explain the ilimaquinone-induced anticancer effect. In brief, it is suggested that ilimaquinone (25) induces its antiproliferative effect through the G1 arrest of the cell cycle and the up-regulation and nuclear translocation of CHOP/GADD153 [32]. Bioassay-guided 
isolation from the marine sponge Hippospongia sp., collected at Palau, led to the isolation of three sesquiterpene quinone metabolites: ilimaquinone (25), 5-epi-ilimaquinone (24), and 5-epi-isospongiaquinone (34) (Figure 2). The cytotoxicity against the NCI-H460, HepG2, SF-268, MCF-7, HeLa, and HL-60 human tumor cell lines, the inhibitory effects on the maturation of starfish oocytes, and cell cycle arrest in the HepG2 cell line were evaluated [47].

Figure 2. Polyfibrospongols, ilimaquinones, smenospongines and related compounds.

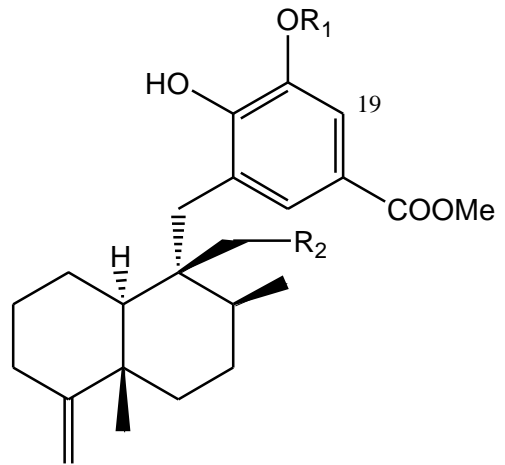

$20 \mathrm{R}_{1}=\mathrm{Me} \mathrm{R}_{2}=\mathrm{H} \quad$ polyfibrospongol $\mathrm{A}$

$21 \mathrm{R}_{1}=\mathrm{Me}, \mathrm{R}_{2}=\mathrm{OH} \quad$ polyfibrospongol $\mathrm{B}$

$22 \mathrm{R}_{1}=\mathrm{Me}, \mathrm{R}_{2}=\mathrm{OH}, 19-\mathrm{OH}$ 19-hydroxy-polyfibrospongol $\mathrm{B}$

$23 \mathrm{R}_{1}=\mathrm{R}_{2}=\mathrm{H} \quad$ smenospondiol<smiles>[R]C1=CC2C([R])=CC(=O)C2=C(C[C@]2(C)[C@@H](C)CC[C@]3(C)C(=C)CCC[C@@H]32)C1=O</smiles>

$24 \mathrm{R}=\mathrm{OMe}$

5-epi-ilimaquinone

$29 \mathrm{R}=\mathrm{NH}\left(\mathrm{CH}_{2}\right)_{2} \mathrm{Ph} \quad$ 5-epi-smenospongidine

$31 \mathrm{R}=\mathrm{NH}\left(\mathrm{CH}_{2}\right)_{2} \mathrm{CHMe}_{2}$ 5-epi-smenospongiarine

$33 \mathrm{R}=\mathrm{NHCH}_{2} \mathrm{CHMe}_{2}$ 5-epi-smenospongorine

$34 \mathrm{R}=\mathrm{OMe}, \Delta^{3} \quad$ 5-epi-isospongiaquinone

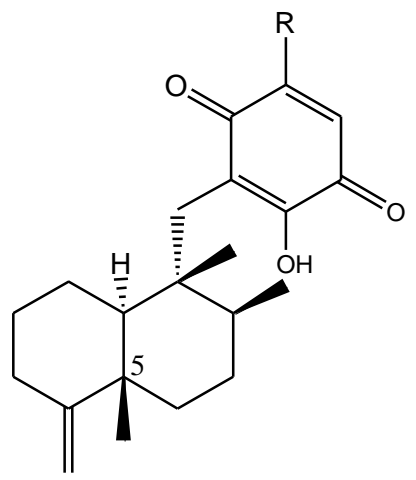

$25 \mathrm{R}=\mathrm{OMe}$

ilimaquinone

$26 \mathrm{R}=\mathrm{NH}-\mathrm{CH}_{2}-\mathrm{COOH}$ glycinylilimaquinone

$27 \mathrm{R}=\mathrm{OH}$

smenoquinone

$28 \mathrm{R}=\mathrm{NH}\left(\mathrm{CH}_{2}\right)_{2} \mathrm{Ph}$ smenospongidine

$30 \mathrm{R}=\mathrm{NH}\left(\mathrm{CH}_{2}\right)_{2} \mathrm{CHMe}_{2}$ smenospongiarine

$32 \mathrm{R}=\mathrm{NHCH}_{2} \mathrm{CHMe}_{2}$ smenospongorine<smiles>C=C1CCC[C@H]2[C@@]1(C)CC[C@@H](C)[C@@]2(C)CC1=C(O)C(OCC)=CC(=O)C1=O</smiles>

35 smenortoquinone

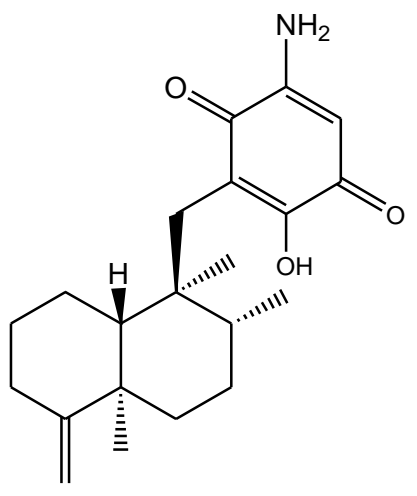

36 smenospongine

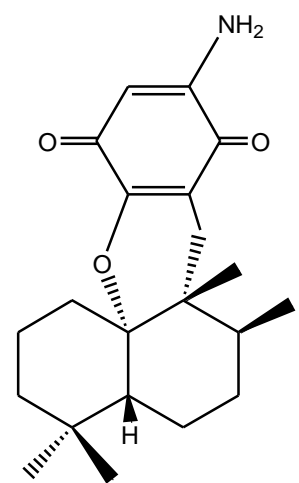

37 cyclosmenospongine 
One compound closely linked to those above is glycinylilimaquinone (26), a metabolite isolated from a specimen from the genus Fasciosponia from the Phillipines, its structure having being determined by spectroscopic analysis and chemical synthesis [48,49]. This structure displayed cytotoxic activity, with $\mathrm{IC}_{50}=7.8 \mu \mathrm{g} / \mathrm{mL}$, against a human carcinoma tumor cell line (HT-29). However, when it was tested against P-388 mouse lymphoma in vivo, the maximum dose tolerated did not display cytotoxic activity.

Other compounds with free hydroxyl and/or amino functions on the benzo(hydro)quinone ring have been isolated from the genus Smenospongia. Bioassays performed on the dichloromethane extract of different species of this genus revealed both cytotoxic and antibacterial activities. From this extract, smenosquinone (27), smenospongidine (28), smenospongiarine (30), smenospongorine (32) and smenorthoquinone (35) were isolated [50]. The cytotoxicity of some of these compounds was assessed against L.1210 leukemia cells. The results for smenoquinone, smenospongiarin and smenortoquinone were $\mathrm{IC}_{50}: 2.5,4.0$ and $1.5 \mu \mathrm{g} / \mathrm{mL}$, respectively.

The methanol-chloroform extract of several species of the genus Smenospongia also afforded smenospongin (36), from the enantiomeric series with respect to the above described compounds. Smenospongin (36), which has also been isolated from Dactylospongia elegans, showed promising biological activities: cytotoxicity against L-1210 leukemia cells with a $\mathrm{LD}_{50}$ of $1 \mu \mathrm{g} / \mathrm{mL}$. Smenospongine (36) induced erythroid differentiation and G1 phase arrest of K562 chronic myelogenous leukemia cells. In that study, the effect of smenospongine (36) on the cell cycles of other leukemia cells, including HL60 human acute promyelocytic leukemia cells and U937 human histiocytic lymphoma cells, was investigated by flow cytometric analysis. Smenospongine (36) induced dose-dependent apoptosis in HL60 and U937 cells. Smenospongine (36) treatment increased the expression of p21 and inhibited the phosphorylation of Rb in K562 cells, suggesting the p21-Rb pathway plays an important role in G1 arrest in K562 cells. However, based on a luciferase assay using transfected K562 cells, the p21 promoter was not activated by smenospongine (36) treatment. Smenospongine might induce p21 expression via a mechanism other than the transactivation of the p21 promoter [51].

D. elegans, from Papua Nueva Guinea and Thailand, contains a total of 17 merosesquiterpenoids, among which are (+)-epi-smenospongiarin (31) and (+)-epi-smenospongidin (29) [46]. These compounds were assayed in vitro against solid tumor models (A-549, HT-29 and B16/F10) and leukemia cells (P-388), (+)-epi-smenospongiarin (31), with $\mathrm{IC}_{50}$ values between 0.6 and $0.9 \mu \mathrm{g} / \mathrm{mL}$ being of particular interest.

A new sesquiterpene aminoquinone, 5-epi-smenospongorine (33), together with nine known sesquiterpene quinone/phenols, were isolated from the marine sponge Dactylospongia elegans. The structure-activity relationship study of these compounds revealed that the quinone skeleton is indispensable and the amino group plays an important role for their differentiation-inducing activity to K562 cells into erythroblast [52]. The new sesquiterpenoid aminoquinone, cyclosmenospongine (37), containing a dihydropyran ring, was isolated from an Australian marine sponge Spongia sp., along with the known metabolites, smenospongiarine (30), ilimaquinone (25) and smenospongine (36) [53].

A unified synthesis of several quinone sesquiterpenes is described by Ling et al. [54].

Avarol (38), a sesquiterpene hydroquinone, and its quinone derivative avarone (49) (Figure 3) are secondary metabolites isolated from the marine sponge Dysidea avara. Both compounds were first 
discovered as anti-leukemia agents in vitro and in vivo, and later it was found that they had an in vitro inhibitory capacity against HIV-1 [55-60]. Controlled clinical studies revealed, however, that it was not efficient in the clinical treatment of patients with AIDS. Additionally, the potent T-lymphotropic cytostatic activity shown by avarol (38), and its low toxicity in mice, its ability to cross the blood-brain barrier and its ability to stimulate the synthesis of interferon make both these compounds optimum candidates for transformations aimed at improving their cytostatic and antiviral activity [12-17,55-60].

Figure 3. Avarols and avarones.
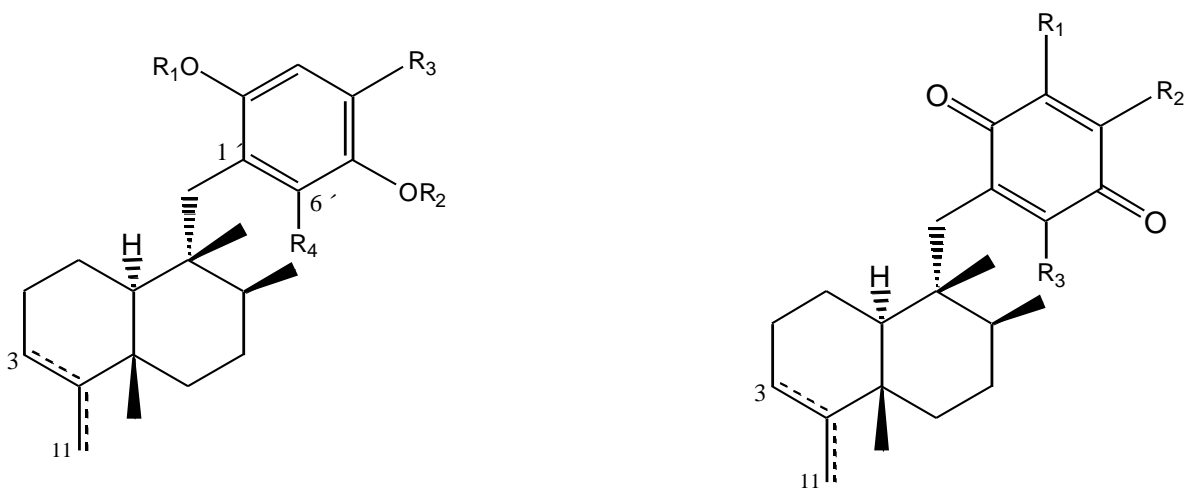
$38 \Delta^{3}, \mathrm{R}_{1}=\mathrm{R}_{2}=\mathrm{R}_{3}=\mathrm{R}_{4}=\mathrm{H}$
avarol
$39 \Delta^{4(11)}, \mathrm{R}_{1}=\mathrm{R}_{2}=\mathrm{R}_{3}=\mathrm{R}_{4}=\mathrm{H}$
neoavarol
$40 \Delta^{3}, \mathrm{R}_{1}=\mathrm{R}_{2}=\mathrm{R}_{3}=\mathrm{H}, \mathrm{R}_{4}=\mathrm{OH}$
6'-hydroxyavarol
6'-acetoxyavarol
$41 \Delta^{3}, \mathrm{R}_{1}=\mathrm{R}_{2}=\mathrm{R}_{3}=\mathrm{H}, \mathrm{R}_{4}=\mathrm{OAc}$
monoaceylavarol
$42 \Delta^{3}, \mathrm{R}_{1}=\mathrm{Ac}, \mathrm{R}_{2}=\mathrm{R}_{3}=\mathrm{R}_{4}=\mathrm{H}$
6'-hydroxy-5'-acetylavarol

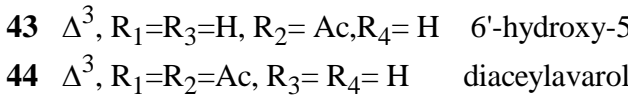
$45 \Delta^{3}, \mathrm{R}_{1}=\mathrm{R}_{2}=p$-Br-benzoyl, $\mathrm{R}_{3}=\mathrm{R}_{4}=\mathrm{H}$
2',5-O-(4-bromobenzoyl)avarol

$46 \Delta^{3}, \mathrm{R}_{1}=\mathrm{R}_{2}=\mathrm{R}_{3}=\mathrm{R}_{4}=\mathrm{H}, 3^{\prime}-\mathrm{SPh}$ thioavarol derivative

$47 \Delta^{3}, \mathrm{R}_{1}=\mathrm{R}_{2}=\mathrm{R}_{4}=\mathrm{H}, \mathrm{R}_{3}=\mathrm{SPh}$ thioavarol derivative

$48 \Delta^{4(11)}, \mathrm{R}_{1}=\mathrm{R}_{2}=\mathrm{R}_{3}=\mathrm{R}_{4}=\mathrm{H} ; 8,9,10-$ epi arenarol
$49 \Delta^{3}, \mathrm{R}_{1}=\mathrm{R}_{2}=\mathrm{R}_{3}: \mathrm{H} \quad$ avarone

$50 \Delta^{4(11)}, \mathrm{R}_{1}=\mathrm{R}_{2}=\mathrm{R}_{3}: \mathrm{H} \quad$ neoavarone

$51 \Delta^{3}, \mathrm{R}_{1}=\mathrm{R}_{3}: \mathrm{H}, \mathrm{R}_{2}=\mathrm{OMe} \quad 4$ '-methoxyavarone

$52 \Delta^{4(11)} \mathrm{R}_{1}=\mathrm{R}_{3}: \mathrm{H}, \mathrm{R}_{2}=\mathrm{OMe} \quad 4^{\prime}$-methoxyneoavarone

$53 \Delta^{3}, \mathrm{R}_{1}=\mathrm{OH}, \mathrm{R}_{2}=\mathrm{R}_{3}: \mathrm{H} \quad 3$ '-hydroxyavarone

$54 \Delta^{3}, \mathrm{R}_{1}=\mathrm{R}_{2}=\mathrm{H}, \mathrm{R}_{3}$ : OMe 6'-methoxyavarone

$55 \Delta^{3}, \mathrm{R}_{1}=\mathrm{R}_{2}=\mathrm{H}, \mathrm{R}_{3}$ : OAc 6'-acetoxyxyavarone

$56 \Delta^{3}, \mathrm{R}_{1}=\mathrm{R}_{3}=\mathrm{OH}, \mathrm{R}_{2}: \mathrm{H} \quad 3^{\prime}, 6^{\prime}$-dihydroxyavarone

$57 \Delta^{3}, \mathrm{R}_{1}=\mathrm{H}, \mathrm{R}_{2}=\mathrm{OMe}, \mathrm{R}_{3}$ : OH $\quad 6^{\prime}$-hydroxy-4'-methoxyavarone

$58 \Delta^{3}, \mathrm{R}_{1}=\mathrm{R}_{3}=\mathrm{H}, \mathrm{R}_{2}=\mathrm{NHMe} \quad 4^{\prime}$-(methylamino)avarone

$59 \Delta^{3}, \mathrm{R}_{1}=\mathrm{NHMe}, \mathrm{R}_{2}=\mathrm{R}_{3}=\mathrm{H} \quad 3$-(methylamino)avarone $60 \quad \Delta^{3}, \mathrm{R}_{1}=?^{2} \mathrm{R}_{2} \sim \sim \mathrm{R}_{3}=\mathrm{H} \quad 33^{\prime}, 4^{\prime}$-(ethylelendithio)avarone

$61 \Delta^{3}, \mathrm{R}_{1}=\mathrm{NH}\left(\mathrm{CH}_{2}\right)_{2} \mathrm{SO}_{3} \mathrm{H} \mathrm{R}_{2}=\mathrm{R}_{3}=\mathrm{H}$ melemeleone A

$62 \Delta^{3}, \mathrm{R}_{1}=\mathrm{R}_{3}=\mathrm{H}, \mathrm{R}_{2}=\mathrm{NH}\left(\mathrm{CH}_{2}\right)_{2} \mathrm{SO}_{3} \mathrm{H}$ melemeleone $\mathrm{B}$

$63 \Delta^{4(11)}, \mathrm{R}_{1}=\mathrm{R}_{2}=\mathrm{R}_{3}=\mathrm{R}_{4}=\mathrm{H} ; 8,9,10$-epi arenarone

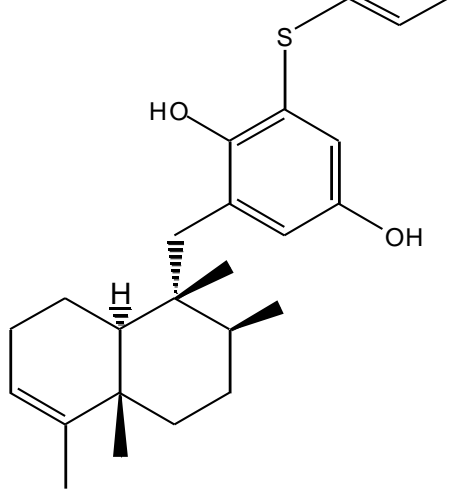

$\mathbf{6 4}$ thiosalicylic derivative of avarol

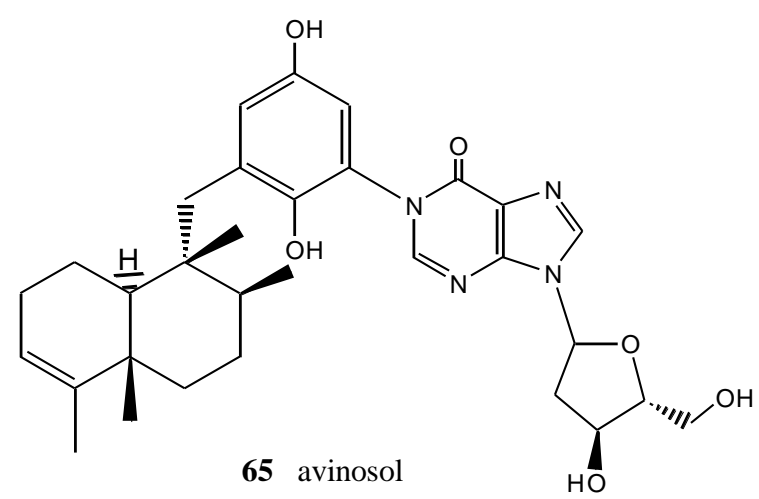


The first avarone analogues were obtained by semisynthesis. Among the main substitutions are those performed on the quinone ring, including hydroxyl, methylamino, ethylamino, and glucosamine groups and different essential amino acids at positions 3' or 4' [56,61]. Cytostatic activity was assayed by analyzing the capacity of these compounds to inhibit the growth of fibroblasts, lymphocytic leukemia and lymphoblastic B and T cells. Avarol (38) and avarone (49) showed very similar inhibitory activity against the cell lines assayed $\left(\mathrm{IC}_{50}=13.9-15.6 \mu \mathrm{M}\right)$, as did the methyl, ethyl and glucosylaminated analogues and the alaninyl, phenylalaninyl and leucinyl derivatives. By contrast, the serinyl and cysteinyl derivatives were significantly less active. Antiviral activity was evaluated against the following viral types: HIV-1, ASFV, HSV-1, HSV-2, polio and VSV. Because of its activity $\left(\mathrm{IC}_{50}=0.04 \mu \mathrm{M}\right.$ HSV-1 and $0.2 \mu \mathrm{M} \mathrm{HSV}-2$ ), acyclovir is used like control compound against herpes simplex. Avarone (49) showed a more potent activity against HIV-1 $\left(\mathrm{IC}_{50}=1.5 \mu \mathrm{M}\right)$ than avarol (38) $\left(\mathrm{IC}_{50}=2.9 \mu \mathrm{M}\right)$ in vitro. Among the derivatives of avarone, modification in the quinone ring always afforded a loss of anti-HIV-1 potential, with the exception of leucinyl- and cysteicyl-avarone, which were as potent as avarone (49), the latter derivative being even more selective.

All the derivatives selectively inhibited polio virus, but were almost completely inactive against the other viruses assayed. Against polio virus, avarol (38), avarone (49) and the 3'-methyl and 3'-ethyl aminoderivatives were more potent and selective inhibitors. The 3'-substituted analogues maintained potency and selectivity, while the 4'-substituted analogues showed a significantly lower potency and in some cases selectivity, the only exceptions being the 4'serinyl and 4'-cysteinyl derivatives of avarone.

Different derivatives of avarol and avarone have been isolated from other species of the genus Dysidea. These included, neoavarol (39), neoavarone (50), 4'-methoxyavarone (51) and 4'-methoxyneoavarone (52) isolated from a specimen in Okinawa [62], while from the extract of Dysidae cinera (collected in the Red Sea), 6'-hydroxyavarol (40), 6'-acetoxyavarol (41), 3'-hydroxyavarone (53), 6'-acetoxyavarone $\quad(\mathbf{5 5}), \quad$ 3',6'-dihydroxyavarone $\quad$ (56) and 6'-hydroxy-4'-methoxyavarone (57) were isolated [63]. Some of these compounds showed cytotoxic, antimicrobial and anti-HIV properties. The results of cytotoxicity assays against P-388 mouse lymphoma indicated high potency for 3'-hydroxyavarone (53), 6'-acetoxyavarol (41) and 3,6'-dihydroxyavarone (56), with $\mathrm{IC}_{50}$ values of $0.6,<0.6$ and $1.2 \mu \mathrm{g} / \mathrm{mL}$, respectively.

Additionally, and related to the above, from different extracts of Dysidea avara collected from different places (Japan, the Solomon Islands, and others), minor metabolites, analogues of avarol and avarone, were isolated: monoacetylavarol (42), diacetylavarol (44), 6'-hydroxy-5'-acetylavarol (43), 4'-methylaminoavarone (58), melemeleone A (61) and melemeleone B (62). These substances were subjected to different biological activity assays both with regard to their cytotoxicity and their capacity for enzyme inhibition [54,64-66]. The cytotoxicity assays performed for diacetylalvarol (44) revealed levels comparable with those of avarol (38), both in tests with Artemia salina (avarol $\mathrm{LD}_{50}=0.18 \mathrm{ppm}$; diacetylavarol, $\mathrm{LD}_{50}=0.15 \mathrm{ppm}$ ) and potato disk assays (avarol, 64\% inhibition; diacetylavarol, 55\% inhibition). Regarding the values for enzyme inhibition, only melemeleone B (62) proved to have a certain activity against PTK pp60 ${ }^{\mathrm{v}-\mathrm{sarc}}$ (dose: $20 \mu \mathrm{g} / \mathrm{mL}$ ) with an $\mathrm{IC}_{50}=28 \mu \mathrm{M}$.

Nine alkyl(aryl)thio derivatives of avarone were synthesized by nucleophilic addition of thiols or thiophenol to avarone, and their cytotoxicity was compared that of aminoavarones. Most derivatives showed cytotoxic activity against tumor cell lines (human cervical carcinoma, HeLa cells, human melanoma Fem-X and human leukemia K-562), with $\mathrm{IC}_{50}$ values lower than $10 \mu \mathrm{M}$ for some of these, 
in particular those with electron-donating substituents. Most compounds showed activity against all three cell lines, but leukemia cells were generally the most susceptible, with $\mathrm{IC}_{50}$ values similar to cisplatin for some methylamino and methoxyavarone derivatives. The exceptions were 4'-(methylamino)avarone (58) and 3',4'-(ethylenedithio)avarone (60), which were more active against melanoma cells, although overall the latter compound showed low activity. The most active compound was 4'-(methylamino)avarone (58), with an $\mathrm{IC}_{50}$ value of $2.4 \mu \mathrm{M}$ against melanoma Fem-X cells, and no cytotoxicity against normal lymphocytes [31]. A highly efficient total synthesis of (+)-avarone, (+)-avarol, (-)-neoavarone, (-)-neoavarol and (+)-aureol has been achieved [67]. An in vitro cytotoxicity assay against U937 human histiocytic lymphoma cells determined the order of cytotoxic potency $((-)$-neoavarone $>(+)$-avarone $>(+)$-aureol $>(+)$-avarol $>(-)$-neoavarol) and some aspects of their structure-activity relationships [67].

Upon acylation, avarol (38) afforded several compounds, two of them2',5'-O-(4-bromobenzoyl)avarol (45) and diacetylavarol (44)-showed cytotoxicity against Hepa (human hepatoma) and KB cell lines, respectively [68]. The semisynthesis of 13 new thioavarol derivatives and an in vitro evaluation of the photodamage response induced by UVB irradiation were described. The ability of the thioavarol derivatives prepared to inhibit NF- $\kappa$ B activation and TNF- $\alpha$ generation in HaCaT cells, as well as their antioxidant capacity in human neutrophils, was also studied. The two monophenyl thioavarol derivatives 46 and 47 lacked cytotoxicity and were considered promising UVB photoprotective agents owing to their potent inhibition of NF- $\kappa$ B activation, with a mild antioxidant pharmacological profile [69]. A thiosalicylic derivative $\mathbf{6 4}$ of avarol was found to be a potent inhibitor of superoxide generation in human neutrophils, and it also potently inhibited $\mathrm{PGE}_{2}$ generation in the HaCaT human keratinocyte cell line [70]. 3'-methylaminoavarone (59) had the best antiproliferative profile, owing to its inhibition of $3 \mathrm{H}$-thymidine incorporation into $\mathrm{HaCaT}$ cells, with a potency similar to the reference compound anthralin [70]. Avinosol (65), a new merotepenoid isolated from the marine sponge Dysidea sp. collected in Papua New Guinea, appeared to be the first example of a naturally occurring meroterpenoid-nucleoside conjugate, and showed anti-invasion activity in cell-based assays [71].

Two sesquiterpenoids with a quinone and hydroquinone moiety, respectively, were isolated from the marine sponge Dysidea arenaria: arenarol (48) and arenarone (63). These compounds showed cytotoxic activity when assayed against P-388 leukemia cells, with $\mathrm{ED}_{50}=17.5 \mu \mathrm{g} / \mathrm{mL}$ for arenarol (48) and $\mathrm{ED}_{50}=1.7 \mu \mathrm{g} / \mathrm{mL}$ for arenarone (63) [72]. Arenarol (48) showed DPPH radical scavenging activity with an $\mathrm{IC}_{50}$ value of $19 \mu \mathrm{M}$ [73].

\section{Terpenylquinones with a Labdane-Type Decalin Ring}

Two new bioactive derivatives, wiedendiol A (66) and wiedendiol B (67) (Figure 4), were isolated from the marine sponge Xestospongia wiedenmayeri, collected in the Bahamas [74]. The absolute configuration of these compounds was determined by chemical synthesis of wiedendiol A (66), performed from (+)-sclareolide [75]. The CETP-SPA inhibition assays carried out with these compounds revealed an $\mathrm{IC}_{50}=5 \mu \mathrm{M}$ in both cases. Later, the inhibition of CETP was verified using a precipitation method to separate lipoproteins after incubation of HDL radiolabeled with LDL and CETP. In this assay, wiedendiol A (66) and B (67) had an $\mathrm{IC}_{50}$ of 1.0 and $0.6 \mu \mathrm{M}$, respectively. 
Wiedendiol $\mathrm{B}$ is a ten-fold stronger inhibitor of cyclooxigenase- 2 than the reference compound indomethacine [76].

There are some compounds with a labdane-type decalin that also have a fourth ring, through an oxygen (most times) or carbon bridge between the decalin and the benzo(hydro)quinone ring. For example, structures with a fourth five-membered oxygen ring, in this case spiranic, are the corallidyctals A (68), B (69), C (70) and D (71) isolated from the marine sponge Aka (Siphonodyctio) corallifagum $[77,78]$. Both corallidytal A (68) and B (69) inhibit $\mathrm{PKC}$ with an $\mathrm{IC}_{50}=28 \mu \mathrm{M}$, while assays addressing another cAMP-dependent kinase did not afford inhibition at concentrations of $300 \mu \mathrm{M}$, indicating its selectivity. Further, the assays revealed selectivity against the $\alpha$ isoform of PKC [77]. Corallidyctals C (70) and D (71) were tested in antiproliferative assays using cultures of mouse fibroblasts and activity was linked to the presence of the ortho-hydroquinone moiety [78].

Figure 4. Wiedendiols, corallidictyals, chromazonarols and puupehenols.

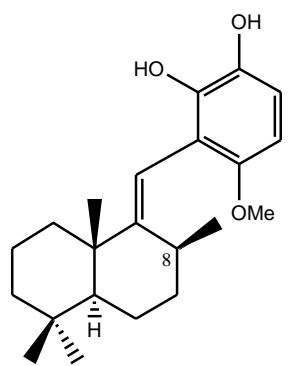

66 wiedendiol A $\left(\Delta^{8}\right)$ 67 wiedendiol B

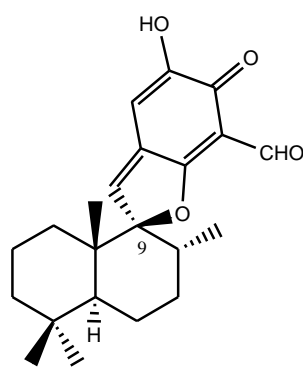

68 corallidictyal A

69 corallidictyal B (9-epi)

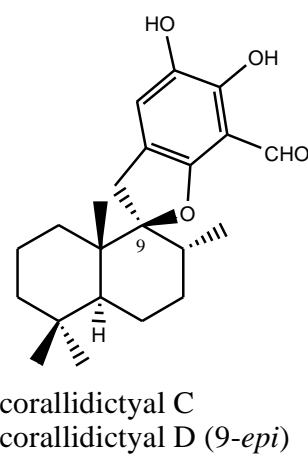

70 corallidictyal C 71 corallidictyal D $(9-e p i)$

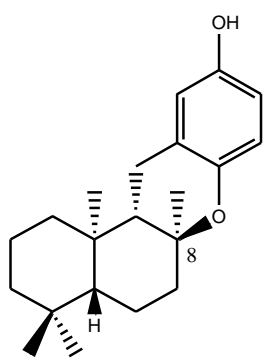

72 chromazonarol

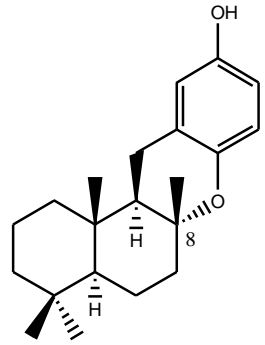

73 ent-chromazonarol 74 8-epi-chromazonarol

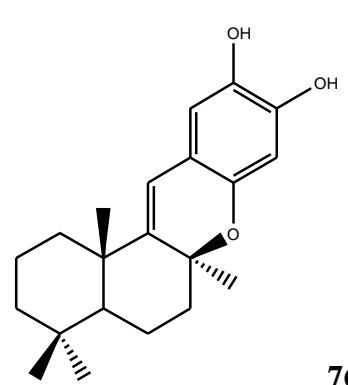

75 puupehenol

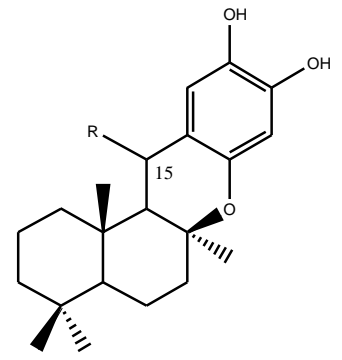
76 R: $\alpha \mathrm{CN}$ 15-cyanopuupehenol
77 R: R: $\alpha \mathrm{MeO}$ 15 $\alpha$-methoxypuupeheno $78 \mathrm{R}:=\mathrm{O} \quad 15$-oxopuupehenol

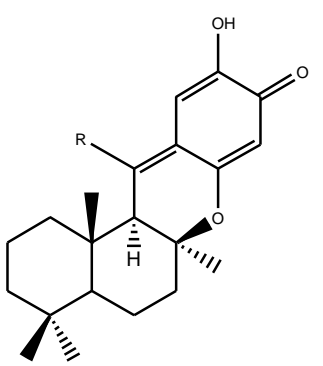

$79 \mathrm{R}=\mathrm{H}$ puupehenone $80 \mathrm{R}=\mathrm{CN}$ cyanopuupehenone

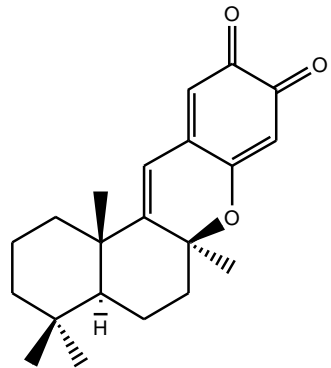

81 puupehedione

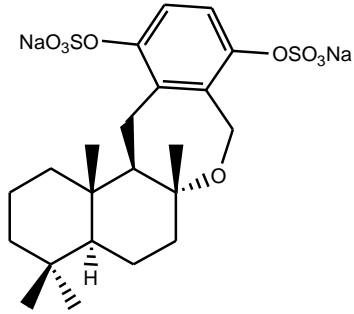

82 cyclosiphonodictyol bis-sulfate A

Of the compounds with a fourth six-membered oxygen ring, the first is ent-chromazonarol (73), isolated from Dysidea pallescens [79], whose structure was confirmed by chemical synthesis performed from (-)-sclareol [80]. Its epimer, 8-epichromazonarol (74), was isolated from Smenospongia aurea [81]. Assays on cytotoxic activity were performed against P-388, A-549. HT-29 
and MEL-28 cells, and in all cases an $\mathrm{IC}_{50}=15.9 \mu \mathrm{M}$ was obtained for ent-chromazonarol (73). Chromazonarol (72), isolated from the brown alga, was inactive $\left(\mathrm{IC}_{50}>10 \mu \mathrm{g} / \mathrm{mL}\right)$ against the $\mathrm{KB}$, Bel-7402, PC-3M, Ketr 3 and MCF-7 human tumor cell lines [82]. An enantioselective cyclisation of 2-(polyprenyl)phenol derivatives to afford polycyclic terpenoids bearing a chroman skeleton such as $(-)$-chromazonarol by a new artificial cyclase has been described [83].

Two metabolites were obtained from one species of the genus Verongida: 15-cyanopuupehenol (76) and 15-cyanopuupehenone, whose structure is intimately related to that of puupehenol (75) and puupehenone (80), the latter isolated from Stronylophora hartmani, collected in deep waters off the Bahamas [80,84-87]. Activity assays performed on puupehenone (79) revealed cytotoxic activity against different neoplastic lines, with an interesting $\mathrm{IC}_{50}=0.5 \mu \mathrm{M}$ against A-549 and HT-29, and even better inhibition values against the synthesis of DNA and RNA ( 0.3 and $0.4 \mu \mathrm{g} / \mathrm{mL}$, respectively). Also, antimicrobial assays provided positive results, especially against Penicilliium notatum and Aspergillus oryzae. However, in the case of cyanopuupehenone (78), only its cytotoxicity against HT-29 human colon carcinoma, with an $\mathrm{IC}_{50}=1-2.5 \mu \mathrm{g} / \mathrm{mL}$, is of interest.

Puuppehenol analogues have been found by studying different species of the genus Hyrtios, collected in Hawaii [84] (from which 15 $\alpha$-methoxypuupehenol (77), the product of methanol manipulation, was isolated) and New Caledonia (from which 15-oxopuupehenol (78) was isolated) [86]. $15 \alpha$-methoxypuupehenol showed cytotoxic activity $\left(\mathrm{IC}_{50}=6 \mu \mathrm{g} / \mathrm{mL}\right.$ ) against $\mathrm{KB}$ neoplastic cells. Puupehenone (80) was isolated from a sponge of the genus Verongida, collected in Hawaii, together with other derivatives of this, among which puupehenione (81) [85] is of interest because it is one of the few orthoquinones included in this review. Bioactivity assays carried out on this compound afforded minimum inhibitory concentration values between 1 and $2 \mu \mathrm{g} / \mathrm{mL}$ for all the neoplastic cell lines analyzed. The antimicrobial tests afforded inhibition halos between 10 and $17 \mathrm{~mm}$.

Several routes towards puupehenone-related metabolites have been achieved [88-90]. Puupehenone (79) and related compounds were selected in the course of a blind screening for new potential inhibitors of angiogenesis; some of them completely inhibited in vivo angiogenesis in the CAM assay at doses equal or lower than $30 \mathrm{nM} / \mathrm{egg}$. They also inhibited the endothelial cell production of urokinase and invasion. The simplicity of their structures and the feasibility of their synthesis make them attractive compounds for further evaluation in the treatment of angiogenesis-related pathologies [91]. Puupenehone analogues from an Indo-Pacific Hyrtios sponge showed bioactivity in a soft-agar cytotoxicity test [92].

The only case of compounds with a further six-membered ring is cyclosiphonodictyol bis-sulfate A (82), a compound isolated from the marine sponge Siphonodictyon coralliphagum. This compound showed inhibitory activity against the binding of $\left[{ }^{3} \mathrm{H}\right]-\mathrm{LTB}_{4}$ to human neutrophils, with $\mathrm{IC}_{50}=44.5 \mu \mathrm{M}[93]$.

\section{Terpenylquinones with a Halimane-Type Decalin Ring}

Within this group, the first is mamanuthaquinone (83) (Figure 5), a cytotoxic metabolite of Fasciospongia sp. collected in the Fiji islands [94]. Activity assays revealed a certain toxicity, especially against HCT-116 human colon carcinoma ( $\left.\mathrm{IC}_{50}=2 \mu \mathrm{g} / \mathrm{mL}\right)$. However, in vitro anti-HIV activity assays proved to be negative. As indicated above, nakijiquinones J (17), M (18) and P (19) at 
$1 \mathrm{mM}$ were tested for inhibitory activity against EGFR and HER2 tyrosine kinases. Among them, nakijiquinones P (19) exhibited inhibitory activity against EGFR (76\% inhibition) [39].

Other compounds with this type of skeleton are the adociasulfates $\mathbf{8 4}$ and $\mathbf{8 5}$, isolated from a sponge from the genus Haliclona. These two compounds were originally of interest because they were positive in tests studying the inhibition of the ATPase of kinesins, with an $\mathrm{IC}_{50}=10 \mu \mathrm{M}$ for the former and $15 \mu \mathrm{M}$ for the latter [95]. Smenoqualone (86) was isolated from different species of the genus Smenospongia, collected from the Gulf of Aden. This compound appears to be related to a product of acid rearrangement of 5-epi-isospongiaquinone (34), and its structure was determined via its spectroscopic data [96]. The activity assays performed with smenoqualone revealed its inactivity as an antimicrobial, antifungal and cytotoxic agent, suggesting that the presence of a free hydroxyl group on the quinone ring is important for biological activity in this group of compounds. Strongyline A (87), a metabolite isolated from the marine sponge Strongylophora hartmani, showed cytotoxic activity against P-388 leukemia cells $\left(\mathrm{IC}_{50}=13 \mu \mathrm{g} / \mathrm{mL}\right)$ and antiviral activity against Influenza PR-8 $\left(\mathrm{IC}_{50}=6.5 \mu \mathrm{g} / \mathrm{mL}, \mathrm{IT}=9\right)$ [97].

Figure 5. Mamanuthaquinone, smecualone, stronglylin and adociasulfates.

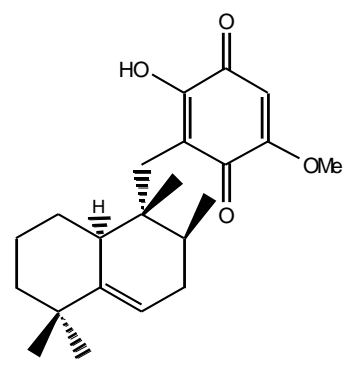

83 mamanuthaquinone

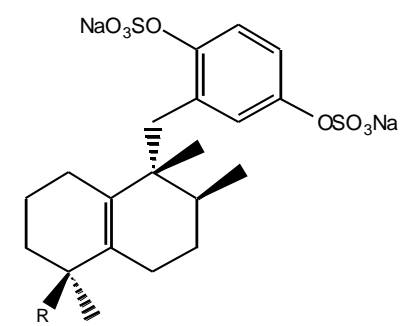

\section{.}

$\mathrm{R}=$

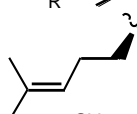

$i^{2}$
- adociasulfate 84

\section{4}
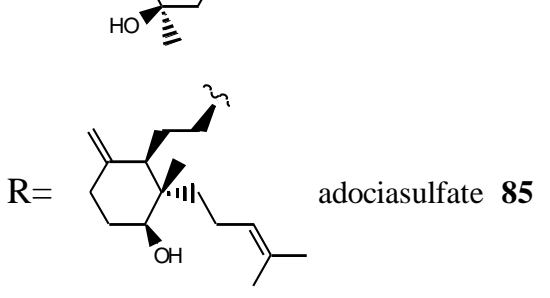

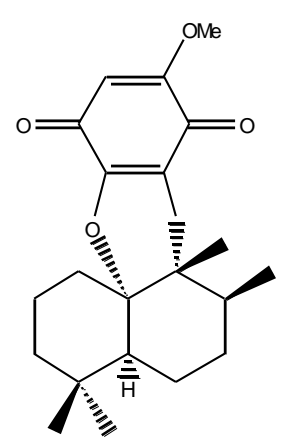

86 smenocualone

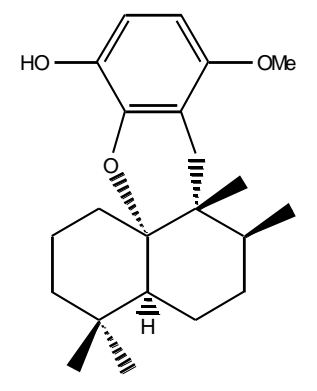

87 strongyline A

\section{Other Related Compounds}

Bolinaquinone (88) (Figure 6) is a cytotoxic sesquiterpene from the genus Dysidea, whose quinone moiety is located on an unusual carbon of the decalin [98]. This compound showed cytotoxic activity against HCT-116 human colon carcinoma $\left(\mathrm{IC}_{50}=1.9 \mu \mathrm{g} / \mathrm{mL}\right)$. The cytotoxicity studies carried out suggest that this compound acts by interfering with or damaging DNA. Dehydroxybolinaquinone (89), isolated from the Hainan sponge Dysidea villosa, showed moderate PTP1B inhibitory activity and cytotoxicity, with $\mathrm{IC}_{50}$ values of 39.5 and $19.5 \mathrm{mM}$, respectively [99]. The sequiterpene aminoquinone dysidine (90) [100], isolated from Dysidea sp., had the strongest hPTP1B inhibitory activity, with an $\mathrm{IC}_{50}$ value of $6.7 \mathrm{mM}$ [99]. Methoxyhalenaquinone (91) from Xestopolospongia carbonara is a tyrosine kinase inhibitor [101]. 
Figure 6. Bolinaquinones, renierins, paniceins, popolohuanones and other compounds.<smiles>[R]C1=C(C[C@]2(C)CC[C@]3(C)C(C)=CCC[C@H]3[C@@H]2C)C(=O)C(OC)=CC1=O</smiles>

$88 \mathrm{R}_{1}=\mathrm{H}, \mathrm{R}_{2}=\mathrm{OMe}$ bolinaquinone $89 \mathrm{R}_{1}=\mathrm{OH} \mathrm{R} \mathrm{R}_{2}=\mathrm{OMe}$ 21-dehydroxybolinaquinone $90 \mathrm{R}_{1}=\mathrm{OH} \mathrm{R} 2=\mathrm{NH}\left(\mathrm{CH}_{2}\right)_{2} \mathrm{SO}_{3} \mathrm{H}$ dysidine<smiles>COC1=CC(=O)c2cc(C)c(C(=O)c3occ4c3CCCC4=O)cc2C1=O</smiles>

91 14-methoxyhalenaquinone<smiles>C/C=C1CC[C@H]2C(C)(C)CCC[C@@]2(O)C\C=C\1C</smiles>

92 fulvanin-2<smiles>COc1cc(Cl)c(CCC2(C)C=Cc3cc(O)ccc3O2)c(C)c1C</smiles>

93 panicein $\mathrm{A}_{2}$

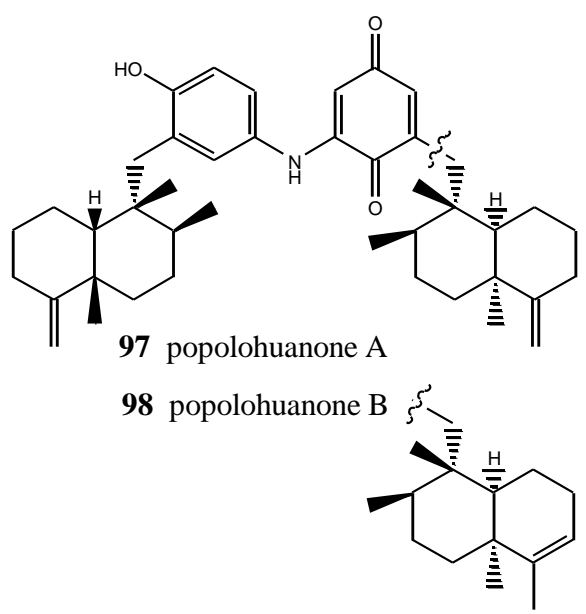

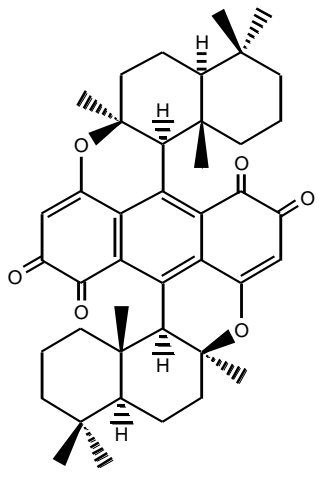

101 dipuupehedione

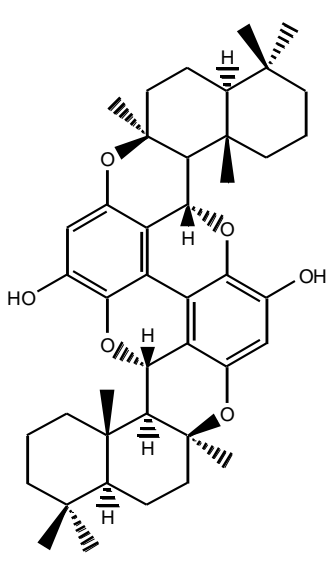

102 bispuupehenone<smiles>CC1=CC(=O)CC(C)(C)[C@H]1CC/C(C)=C/Cc1cc(O)ccc1O</smiles>

95 renierin $\mathrm{A}$<smiles>COC1=CC(C)(C)C(CCC(O)=CCc2cc(O)ccc2O)=C(C)C1=O</smiles>

96 renierin $B$<smiles>[R][R]([R])[R]=[R]([R])[R]</smiles>

$99 \mathrm{R}_{1}=\mathrm{H}, \mathrm{R}_{2}=\mathrm{R}$ popolohuanone $\mathrm{C}$

An important number of metabolites with very diverse structures have been isolated from the genus Reniera, such as carotenes, alkaloids, diacetylenes and terpenequinones. In particular, four metabolites with a sesquiterpene structure were isolated from the species Reniera fulva, with the novelty that they 
did not have the B ring of the decalin, the most significant compound being fulvanin-2 (92) [102]. Additionally, apart from fulvanins, the fractionation of the acetone extract of Reniera mucosa afforded another five compounds with analogous structures: paniceins $\mathrm{A}_{2}(\mathbf{9 3})$ and $\mathrm{F}_{1}(\mathbf{9 4})$, renierins $\mathrm{A}(\mathbf{9 5})$ and B (96), and $p$-hydroquinone [103]. All the compounds obtained from Reniera mucosa were assayed against the P-388, A-549, HT-29 and MEL-28 cell lines with a view to determining their in vitro cytotoxicity. Among them, of interest were panicein $\mathrm{A}_{2}(\mathbf{9 3})\left(\mathrm{ED}_{50}=5 \mu \mathrm{g} / \mathrm{mL}\right.$ against all the lines assayed) and panicein $F_{1}(\mathbf{9 4})\left(\mathrm{ED}_{50}=5 \mu \mathrm{g} / \mathrm{mL}\right.$ against all cell lines except HT-29), the latter showing medium potency in additional DHFR inhibition tests $\left(\mathrm{ED}_{50}=3 \mu \mathrm{g} / \mathrm{mL}\right)$.

New terpenylquinones were isolated from different species of the genus Dysidea; their structures are formed by two subunits, called popolohuanones. Thus, from a specimen of that genus, collected in Papua New Guinea, popolohuanones A (97) and B (98) were isolated [104], whereas popolohuanones C (99) and D (100) were isolated from Dysidea avara, collected in the Solomon Islands [64]. Cytotoxicity assays for popolohuanone A (97), performed against KB cells at concentrations of 10, 5 and $1 \mu \mathrm{g} / \mathrm{mL}$, proved to be negative. Identical results were obtained in antimycotic activity assays against Candida albicans. Other related compounds were isolated from species of the genus Hyrtios (New Caledonia), such as dipuupehenone (101) and bispuupehenone (102), the latter also found in the species Hyrtios eubamma (Tahiti). Bioactivity assays of these compounds unveiled the cytotoxic activity of dipuupehedione (101) against $\mathrm{KB}$ cells $\left(\mathrm{ED}_{50}=3 \mu \mathrm{g} / \mathrm{mL}\right)$. Popolohuanone $\mathrm{E}(\mathbf{1 0 3})$, a potent topoisomerase II inhibitor with selective cytotoxicity against the A549 non-small cell human lung cancer cell line, was isolated from Dysidea sp. Pohnpei sponges [105], and the biomimetic route to this family of heterocyclic ring systems has been proposed [106]. Popolohuanone A (96) and the new dimeric popolohuanone $\mathrm{F}(\mathbf{1 0 4})$ showed DPPH radical scavenging activity, with an $\mathrm{IC}_{50}$ value of $35 \mu \mathrm{M}[73]$.

A biosynthetic pathway leading to several sesquiterpene quinones is suggested [107].

\section{SAR Studies and Mechanism of Action}

Sesquiterpenoid quinones from marine sponges and their semisynthetic derivatives were compared for cytotoxicity on developing eggs of the sea urchin Strongylocentrotus nudus and Ehrlich carcinoma cells, and for hemolytic activities on mouse red blood cells. Structure-cytotoxicity studies of several marine sesquiterpenoid quinones and their semisynthetic derivativess on developing eggs of the sea urchin Strongylocentrotus nudus and Ehrlich carcinoma cells revealed that the activities of these compounds, with a hydroxyl group at C-20, were higher than their methoxyl and amino groups at this position. Sesquiterpenoid quinones containing a dihydropyran ring had lower activity than non-cyclic compounds. The structure of the terpenoid moieties of the compounds had no significant influence on biological activity. There was a direct correlation between the cytotoxic and hemolytic activities, and the mechanisms of action employed by these compounds against cell membranes have been discussed [108]. Other results from SAR studies appear in the description of the different types of compound.

Regarding the mechanism of action of terpenylquinones, the accumulated data about the biological activity of quinone moieties suggest redox processes and/or Michael-type addition-elimination reactions [31]. Their cytotoxicity has been explained in terms of their ability to undergo redox cycling 
and the generation of reactive oxygen species, which would damage tumor cells [109-111]. NADH/NADH dehydrogenase reduction of the several terpenylnaphthoquinones increases the rate of oxygen consumption, such rates being higher for quinones with more positive redox potentials. In this process, reactive oxygen species are formed in small amounts, which also correlate with the quinone redox potential. Semiquinone derivatives of these quinones are generated under anaerobic conditions and in the presence of NADH/NADH dehydrogenase. Since this enzymatic system is found in mitochondria, a possible pathway in the cytotoxic activity of these terpenylnaphthoquinones could be interference with or the inhibition of mitochondrial respiration, as reported for other naphthoquinone derivatives, in addition to free radical degradation [29,30]. The results obtained with avarone and avarol supported the mechanism of antitumor action via the reactive oxygen radicals [112,113], but there were also indications of the relevance of arylation of biomolecules, such as proteins $[31,114,115]$.

\section{Summary}

The compounds that appear in this review are meroterpenes, compounds of mixed biogenesis isolated from marine sources and mainly from the following genera: Dactylospongia, Dysidea, Euryspongia, Fasciospongia, Fenestraspongia, Haliclona, Polifibospongia, Siphonodictyon, Smenospongia, Stelospongia, Strongylophora, Reniera and Xestospongia. The cytotoxic properties of sesquiterpenequinones or quinols produced by these genera make them viable candidates for continuing the search for analogues with enhanced cytotoxicity, improved selectivity and able to eliminate adverse effects with a view to finding new drugs of marine origin [3,5,19,24-26]. Outstanding among the compounds investigated is 4'-(methylamino)avarone (58), with an $\mathrm{IC}_{50}$ of $2 \mu \mathrm{M}$ against melanoma Fem-X cells, and non-cytotoxic to normal lymphocytes [31].

\section{Acknowledgements}

The author would like to thank the Regional Government of Castile \& Leon (Consejería de Educación, SA-4/2010) and the Ministerio de Ciencia e Innovación CTQ2010-16170.

\section{References}

1. Skropeta, D. Deep-sea natural products. Nat. Prod. Rep. 2008, 25, 1131-1166.

2. Thornburg, C.; Zabriskie, T.M.; McPhail, K.L. Deep-sea hydrothermal: Potencial hot spot for natural products discovery. J. Nat. Prod. 2010, 73, 489-499.

3. Molinski, T.T.; Dalisay, D.S.; Lievens, S.L.; Saludes, J.P. Drug development from marine natural products. Nat. Rev. Drug Discov. 2009, 8, 69-85.

4. Simmons, T.L.; Andrianasolo, E.; McPhail, K.; Flatt. P.; Grewick, W.H. Marine natural products as anticancer drugs. Mol. Cancer Ther. 2005, 4, 333-342.

5. Villa, F.A.; Gerwick, L. Marine natural product drug discovery: Leads for treatment of inflammation, cancer, infections, and neurological disorders. Immunopharmacol. Immunotoxicol. 2010, 32, 228-237.

6. Shi, Q.; Huo, C.; Li, L.; Zhang, M. History retrospection on chemistry research of marine natural products. Zhongcaoyao 2009, 40, 1687-1695. 
7. Fusetani, N. Biotechnological potential of marine natural products. Pure Appl. Chem. 2010, 82, $17-26$.

8. Blunt, J.W.; Copp, B.R.; Munro, M.H.G.; Northcote, P.T.; Prinsep, M.R. Marine natural products. Nat. Prod. Rep. 2010, 27, 165-237.

9. Morris, J.C.; Phillips, A.J. Marine natural products: Synthetic aspects. Nat. Prod. Rep. 2010, 27, 1186-1203.

10. Hill, R.A. Marine natural products. Annu. Rep. Prog. Chem. B Org. Chem. 2009, 105, 150-166.

11. Nagle, D.G.; Zhou, Y.-D. Marine natural products as inhibitors of hypoxic signaling in tumors. Phytochem. Rev. 2009, 8, 415-429.

12. Arai, M.; Kobayashi, M. Chemical biology of marine natural products. Kagaku to Seibutsu 2009, 47, 275-282.

13. Glaser, K.B.; Mayer, A.M.S. A renaissance in marine pharmacology: From preclinical curiosity to clinical reality. Biochem. Pharmacol. 2009, 78, 440-448.

14. Raviña, E. The Evolution of Drug Discovery: From Traditional Medicines to Modern Drugs; Wiley-WCH: Weinheim, Germany, 2010.

15. Bailly, C. Ready for comeback of natural products in oncololoy. Biochem. Pharmacol. 2009, 77, 1447-1457.

16. Cragg, G.M.; Grothaus, P.G.; Newman, D.J. Impact of natural products on developing new anti-cancer agents. Chem Rev. 2009, 109, 3012-3043.

17. Gordaliza, M. Natural products as leads to anticancer drugs. Clin. Transl. Oncol. 2007, 9, 767-776.

18. Gordaliza, M. Terpeny-purines from the sea. Mar. Drugs 2009, 7, 833-847.

19. Lee, K.-H. Discovery and development of natural product-derived chemotherapeutic agents based on a medicinal chemistry approach. J. Nat. Prod. 2010, 73, 500-516.

20. Miljanich, G.P. Ziconotide: Neural calcium channel blocker for treating severe chronic pain. Curr. Med. Chem. 2004, 11, 3029-3040.

21. Cuevas, C.; Francesch, A. Development of Yondelis ${ }^{\circledR}$ (trabectedin, ET-743). A semisynthetic process solves the supply problem. Nat. Prod. Rep. 2009, 26, 322-333.

22. Alday, P.H.; Correia, J.J. Macromolecular interaction of halichondrin B analogues eribulin (E7389) and E-076349 with tubulin by analitical ultacentrifugation. Biochemistry 2009, 48, 7927-7938.

23. Smith, J.A.; Wilson, L.; Azarenko, O.; Zhu, X.; Lewis, B.M.; Littlefield, B.A.; Jordan, M.A. Eribulin binds at microtubule ends to a single site on tubulin to suppress dynamic instability. Biochemistry 2010, 49, 1331-1337.

24. Sladic, D.; Gasic, M.J. Reactivity and biological activity of marine sesquiterpene hydroquinones avarol and related compound from sponges of Order Dictyoceratida. Molecules 2006, 11, 1-33.

25. Motti, C.A.; Bourguet-Kondracki, M.-L.; Longeon, A.; Doyle, J.R.; Llewellyn, L.E.; Tapiolas, D.M.; Yin, P. Comparison of biological properties of several marine sponge-derived sesquiterpenoid quinines. Molecules 2007, 12, 1376-1388.

26. Cragg, G.M.; Newman, D.J. Industrial applications natural products for medicinal purposes. Drugs from nature: Present development and future prospects. In Natural Products in the New Millenium: Prospects and Industrial Applications; Rauter, A.P., Palma, F.B., Justino, J., Araújo, M.E., Dos Santos, S.P., Eds.; Kluwer: Dordrecht, The Netherlands, 2002; pp. 441-461. 
27. Gordaliza, M.; Miguel del Corral, J.M.; Mahiques, M.M.; San Feliciano, A.; García-Grávalos, M.D. Terpenequinone with antitumor activity. PCT Int. Appl. EP 0731078 A1, 1994.

28. Miguel del Corral, J.M.; Castro, M.A.; Gordaliza, M.; Martín, M.L.; Gamito, A.M.; Cuevas, C.; San Feliciano, A. Synthesis and citotoxicity of new heterocyclic terpenylnaphthoquinones. Bioorg. Med. Chem. 2006, 14, 2816-2827.

29. Alegría, A.; Sánchez, S.; Sánchez-Cruz, P.; Nieves, I.; Cruz, N.G.; Gordaliza, M.; Martín-Martín, M.L. Terpenylnaphthoquinones are reductively activated by NADH/NADH dehydrogenase. Toxicol. Environ. Chem. 2005, 87, 237-245.

30. Alegría, A.; Cordones, E.; Marcano, Y.; Sanchez, S.; Gordaliza, M.; Martín-Martín, M.L. Reductive activation of terpenylnaphtoquinones. Toxicology 2002, 175, 167-175.

31. Bozic, T.; Novakovic, I.; Gasic, M.J.; Juranic, Z.; Stanojkovic, T.; Tufegdzic, S.; Kljajic, Z.; Sladic, D. Synthesis and biological activity of derivatives of the marine quinone avarone. Eur. J. Med. Chem. 2010, 45, 923-929.

32. Lu, P.-H.; Chueh, S.-C.; Kung, F.-L.; Pan, S.-L.; Shen, Y.-C.; Guh, J.-H. Illimaquinone, a marine sponge metabolite, displays anticancer activity via GADD153-mediated pathway. Eur. J. Pharmacol. 2007, 556, 45-54.

33. Parks, J.; Gyeltshen, T.; Prachyawarakorn, V.; Mahidol, C.; Ruchirawat, S.; Kittakoop, P. Glutarimide alkaloids and a terpenoid benzoquinone from Cordia globifera. J. Nat. Prod. 2010, 73, 992-994.

34. Kobayashi, J. Chemistry and biology of Okinawan marine natural products. Pure Appl. Chem. 2009, 81, 1009-1018.

35. Shigemori, H.; Madono, T.; Sasaki, T.; Mikami, Y.; Kobayashi, J. Nakijiquinones A and B, new antifungal sesquiterpenoid quinones with an amino acid residue from an Okinawan marine sponge. Tetrahedron 1994, 50, 8347-8354.

36. Kobayashi, J.; Madono, T.; Shigemori, H. Nakijiquinones C and D, new sesquiterpenoid quinones with a hydroxy amino acid residue from a marine sponge inhibiting c-erbB-2 kinase. Tetrahedron 1995, 51, 10867-10874.

37. Takahashi, Y.; Kubota, T.; Kobayashi, J. Nakijiquinones E and F, new dimeric sesquiterpenoid quinones from marine sponge. Bioorg. Med. Chem. 2009, 17, 2185-2188.

38. Takahashi, Y.; Kubota, T.; Ito, J.; Mikami, Y.; Fromont, J.; Kobayashi, J. Nakijiquinones G-I, new sesquiterpenoid quinones from marine sponge. Bioorg. Med. Chem. 2008, 16, 7561-7564.

39. Takahashi, Y.; Ushio, M.; Kubota, T.; Yamamoto, S.; Fromont, J.; Kobayashi, J. Nakijiquinones $\mathrm{J}-\mathrm{R}$, Sesquiterpenoid quinones with an qmine residue from Okinawan marine sponges. $J$. Nat. Prod. 2010, 73, 467-471.

40. Stahl, P.; Kissau, L.; Mazitschek, R.; Huwe, A.; Furet, P.; Giannis, A.; Waldmann, H. Total synthesis and biological evaluation of the nakijiquinones. J. Am. Chem. Soc. 2001, 123, 11586-11593.

41. Shen, Y.-C.; Hsieh, P.-W. New sesquiterpene hydroquinones from a Taiwanese marine sponge Polyfibrospongia australis. J. Nat. Prod. 1997, 60, 93-97.

42. Qiu, Y.; Wang, X.M. A new sesquiterpenoid hydroquinone from the marine sponge Dysidea arenaria. Molecules 2008, 13, 1275-1281. 
43. Haruo, Y.; Hasegawa, T.; Tanaka, H.; Takahashi, T. Total Synthesis of ( \pm )-smenospondiol by titanium(III)-mediated tandem radical cyclization. Synlett 2001, 2001, 1935-1937.

44. Kondracki, M.-L.; Davoust, D.; Guyot, M. Smenospondiol, a biologically active hydroquinone from the sponge Smenospongia sp. J. Chem. Res. (Synop.) 1989, 3, 74-75.

45. Nakamura, H.; Deng, S.; Kobayashi, J.; Ohizumi, Y. Dictyioceratin-A and B, novel antimicrobial terpenoids from Okinawan marine sponge Hippospongia sp. Tetrahedron 1986, 42, 4197-4201.

46. Rodriguez, J.; Quiñoá, E.; Riguera, R.; Peters, B.M.; Abrell, L.M.; Crews, P. The structures and stereochemistry of cytotoxic sesquiterpene quinones from Dactylospongia elegans. Tetrahedron 1992, 48, 6667-6680.

47. Liu, H.; Wang, G.; Namikoshi, M.; Kobayashi, H.; Yao, X.; Cai, G. Sesquiterpene quinones from a marine sponge Hippospongia sp. that inhibit maturation of starfish oocytes and induce cell cycle arrest with HepG2 cells. Pharm. Biol. 2006, 44, 522-527.

48. Kondracki, M.L.; Guyot, M. Biologically active quinine and hydroquinones sesquiterpenoids from the sponge Smenospongia sp. Tetrahedron 1989, 45, 1995-2004.

49. Evans, T.P.; Cornell, L.; Peterson, R.W.; Faulkner, D.J. Isolation and synthesis of a glycine derivative of ilimaquinone from Fasciospongia sp. Nat. Prod. Lett. 1994, 4, 287.

50. Kondracki, M.L.; Guyot, M. Smenospongine: A cytotoxic and antimicrobial aminoquinone isolated from Smenospongia sp. Tetrahedron Lett. 1987, 28, 5815-5818.

51. Kong, D.; Aoki, S.; Sowa, Y.; Sakai, T.; Kobayashi, M. Smenospongine, a sesquiterpene aminoquinone from a marine sponge, induces G1 arrest or apoptosis in different leukemia cells. Mar. Drugs 2008, 6, 480-488.

52. Aoki, S.; Kong, D.; Matsui, K.; Rachmat, R.; Kobayashi, M. Sesquiterpene aminoquinoes from a marine sponge induce erytnroid differentiation in human chronic myelogenous leukemia K562 cells. Chem. Pharm. Bull. 2004, 52, 935-937.

53. Utkina, N.K.; Denisenko, V.A.; Scholokova, O.V.; Virovaya, M.V.; Prokof'eva, N.G. Cyclosmenospongine, a new sequiterpenoid aminoquinone from an Australian marine sponge Spongia sp. Tetrahedron Lett. 2003, 44, 101-102.

54. Ling, T.; Poupon, E.; Rueden, E.J.; Kim, S.H.; Theodorakis, E.A. Unified synthesis of quinone sesquiterpenes based on a radical decarboxilation and quinone addition reaction. J. Am. Chem. Soc. 2002, 124, 12261-12267.

55. Cimino, G.; De Rosa, S.; De Stefano, S.; Cariello, L.; Zanetti, L. Structure of two biologically active sesquiterpenoid amino-quinones from de marine sponge Dysidea avara. Experientia 1982, $38,896$.

56. Cozzolino, R.; De Giulio, A.; De Rosa, S.; Strazzullo, G.; Gašič, M.J.; Sladić, D.; Zlatović, M. Biological activities of avarol derivatives, 1. Amino derivatives. J. Nat. Prod. 1990, 53, 699-702.

57. Müller, W.E.G.; Maidhof, A.; Zahn, R.K.; Schröder, H.C.M.; Gasic, M.J.; Heidemann, D.; Bernd, A.; Kurelec, B.; Eich, E.; Seibert, G. Potent antileukemic activity of the novel cytostatic agent avarone and its analogues in vitro and in vivo. Cancer Res. 1985, 45, 4822-4826.

58. Müller, W.E.G.; Sobel, C.; Sachsse, W.; Diehl-Seifert, B.; Zahn, R.K.; Eich, E.; Kljajić, Z.; Schröder, H.C. Biphasic and differential effects of the cytostatic agents avarone and avarol on DNA metabolism of human and murine T and B lymphocytes. Eur. J. Cancer Clin. Oncol. 1986, 22, 473-476. 
59. Müller, W.E.G.; Sobel, C.; Diehl-Seifert, B.; Maidhof, A.; Schöder, H.C. Influence of the antileukemic and anti-human immunodeficiency virus agent avarol on selected immune responses in vitro and in vivo. Biochem. Pharmacol. 1987, 36, 1489-1494.

60. Sarin, P.S.; Sun, D.; Thornton, A.; Müller, W.E.G. Inhibition of replication of the etiologic agent of acquired immune deficiency syndrome (human T-lymphotropic retrovirus/lymphadenopathyassociated virus) by avarol and avarone. J. Natl. Cancer Inst. 1987, 78, 663-666.

61. De Giulio, A.; De Rosa, S.; Strazzullo, G.; Diliberto, L.; Obino, P.; Marongiu, M.E.; Pani, A.; La Colle, P. Synthesis and evaluation of cytostatic and antiviral activities of 3'- and 4'-avarone derivatives. Antivir. Chem. Chemother. 1991, 4, 223-227.

62. Iguchi, K.; Sahashi, A.; Khono, J.; Yamada, Y. New sesquiterpenoid hydroquinone and quinones from the Okinawan marine sponge (Dysidea sp.). Chem. Pharm. Bull. 1990, 38, 1121-1123.

63. Hirsch, S.; Rudi, A.; Kashman, Y.; Loya, Y. New avarone and avarol derivatives from the marine sponge Dysidea cinerea. J. Nat. Prod. 1991, 54, 92-97.

64. Alvi, K.A.; Diaz, M.C.; Crews, P.; Slate, D.L.; Lee, R.H.; Moretti, R. Evaluation of new sesquiterpene quinones from two Dysidea sponge species as inhibitors of protein tyrosine kinase. J. Org. Chem. 1992, 57, 6604-6607.

65. Crispino, A.; De Giulio, A.; De Rosa, S.; Strazzullo, G. A New bioactive derivative of avarol from the marine Sponge Dysidea avara. J. Nat. Prod. 1989, 52, 646-648.

66. De Giulio, A.; De Rosa, S.; Di Vincenzo, G.; Strazzullo, G. Further bioactive derivative of avarol from Dysidea avara. Tetrahedron 1990, 46, 7971-7976.

67. Sakurai, J.; Oguchi, T.; Watanabe, K.; Abe, H.; Kanno, S.-I.; Ishikawa, M.; Katoh, T. Highly efficient total synthesis of the marine natural products. (+)-avarone, (+)-avarol, (-)-neoavarone, (-)-neoavarol and (+)-aureol. Chem. Eur. J. 2008, 14, 829-837.

68. Shen, Y.-C.; Lu, C.-H.; Chakraborty, R.; Kuo, Y.-H. Isolation of sesquiterpenoids from sponge Dysidea avara and chemical modification of avarol as potencial antitumor agents. Nat. Prod. Rep. 2003, 17, 83-89.

69. Amigo, M.; Terencio, M.C.; Paya, M.; Iodice, C.; De Rosa, S. Synthesis and evaluation of diverse thio avarol derivatives as potential UVB photoprotectives candidates. Bioorg. Med. Chem. Lett. 2007, 17, 2561-2565.

70. Amigo, M.; Terencio, M.C.; Mitova, M.; Iodice, C.; Paya, M.; De Rosa, S. Potential antipsoriatic avarol derivatives as antioxidants and inhibitors of PGE2 generation and proliferation in HaCaT cell line. J. Nat. Prod. 2004, 67, 1459-1463.

71. Diaz-Marrero, A.R.; Austin, P.; van Soest, R.: Matainaho, T.; Roskelley, C.D.; Roberge, M.; Andersen, R.J. Avinosol, a meroterpenoid-nucleoside conjugate with antiinvasion activity isolated from the marine sponge Dysidea sp. Org. Lett. 2006, 8, 3749-3752.

72. Schmitz, F.J.; Lakshmi, V.; Powell, D.R.; Van der Helm, D. Arenarol and arenarona: Sesquiterpenoids with rearranged drimane skeletons from marine sponge Dysidea arenaria. J. Org. Chem. 1984, 49, 241-244.

73. Utkina, N.K.; Denisenko, V.A.; Krasokhin, V.B. Sesquiterpenoidd aminoquinones from marine sponge Dysidea sp. J. Nat. Prod. 2010, 73, 788-791. 
74. Coval, S.J.; Conover, M.A.; Mierzwa, R.; King, A.; Puar, M.S.; Phife, D.W.; Pai, J.K.; Burrier, R.E.; Ahn, H.S. Widendiol A and B, cholesteryl esther transfer protein inhibitors from marine sponge Xetospongia widenmayeri. Bioorg. Med. Chem. Lett. 1995, 5, 605-610.

75. Chackalamannil, S.; Wang, Y.; Xia, Y.; Czarniecki, M. An efficient synthesis of wiedendiol A from (+)-sclareolide. Tetrahedron Lett. 1995, 36, 5315-5318.

76. Laube, T.; Bernet, A.; Dahse, H.-M.; Jacobsen, I.D.; Seifert, K. Synthesis and pharmacological activities of some sesquiterpene quinines and hydroquinones. Bioorg. Med. Chem. 2009, 17, $1422-1427$.

77. Chan, J.A.; Freyer, A.J.; Carté, B.K.; Hemling, M.E.; Hofmann, G.H.; Mattern, M.R.; Mentzer, M.A.; Westley, J.W. Protein kinase C inhibitors: novel spitosequiterpene aldehydes from a marine sponge Aka (=Siphonodictyon) coralliphagum. J. Nat. Prod. 1994, 57, 1543-1548.

78. Grube, A.; Assman, M.; Lichte, E.; Sasse, F.; Pawlik, J.R.; Loeck, M. Bioactive metabolites from the Caribbean sponge Aka coralliphagun. J. Nat. Prod. 2007, 70, 504-509.

79. Cimino, G.; De Stefano, S.; Minale, L. Chromazonarol, a chroman-sesquiterpenoid from sponge Dysidea pallenscens. Experientia 1975, 31, 1117.

80. Barrero, A.J.; Alvarez-Manzaneda, E.J.; Herrador, M.M.; Chahboun, R.; Galera, P. Synthesis and antitumoral activities of marine ent-chromazonarol and related compounds. Bioorg. Med. Chem. Lett. 1999, 9, 2325-2328.

81. Djura, P.; Stierle, D.B.; Sullivan, B.; Faulkner, D.J. Some metabolites of the marine sponges Smenospongia aurea and Smenospongia (Polyfibrospongia) echina. J. Org. Chem. 1980, 45, 1435-1441.

82. Song, F.; Fan, X.; Xu, X.; Wang, S.; Li, S.; Yang, Y.; Shi, J. Studies on chemical constituents of the brown alga Dictyopteris divaricata. Zhongguo Zhong Yao Za Zhi 2006, 31, 125-128.

83. Hideaki, I.; Kazuaki, I.; Hisashi, Y. A new artificial cyclase for poliprenoids: Enantioselective total synthesis of (-)-chromazonarol, (+)-8-epi-puupehedione and (-)-11'-deoxytaondiol methyl ether. J. Am. Chem. Soc. 2004, 126, 11133-11123.

84. Bourguet-Kondracki, M.-L.; Lacombe, F.; Guyot, M. Methanol adduct of puupehenone, a biologically active derivative from the marine sponge Hyrtios species. J. Nat. Prod. 1999, 62, 1304-1305.

85. Hamann, M.T.; Scheuer, P.J.; Kelly-Borges, M. Biogenetically diverse, bioactive constituents of a sponge, order Verongida: Bromotyramines and sesquiterpene-shikimate derived metabolites. J. Org. Chem. 1993, 58, 6565-6569.

86. Kohmoto, S.; McConnell, O.J.; Wright, A.; Koehn, F.; Thompson, W.; Lui, M.; Snader, K.M. Puupehenone, a cytotoxic metabolite from a deep water marine sponge, Stronglyophora hartmani. J. Nat. Prod. 1987, 50, 336.

87. Nasu, S.S.; Yeung, B.K.S.; Hamann, T.; Scheuer, P.J.; Kelly-Borges, M.; Goins, K. Puupehenone-related metabolites from two Hawaiian sponges, Hyrtios sp. J. Org. Chem. 1995, 60, 7290-7292.

88. Arjona, O.; Garranzo, M.; Mahugo, J.; Maroto, E.; Plumet, J.; Saez, B. Total synthesis of both enantiomers of 15-oxopuupehenol methylendioxy derivatives. Tetrahedron Lett. 1997, 38, 7249-7252. 
89. Barrero, A.J.; Alvarez-Manzaneda, E.J.; Chahboun, R.; Cortes, M.; Armstrong, V. Synthesis and antitumoral activities of puupehedione and related compounds. Tetrahedron 1999, 55, 15181-15208.

90. Alvarez-Manzaneda, E.; Chhboun, R.; Cabrera, E.; Alvarez, E.; Haidour, A.; Ramos, J.M.; Alvarez-Manzaneda, R.; Tapia, R.; Es-Samti, H.; Fernandez, A.; Barranco, I. A convenient enantiospecific route towards bioactive merosesquiterpenes by cationic-resin-promoted Friedel-Crafts alkylation with $\alpha, \beta$-enones. Eur. J. Org. Chem. 2009, 2009, 1139-1143.

91. Castro, M.E.; Gonzales-Iriarte, M.; Barrero, A.F.; Salvador-Tormo, N.; Muñoz-Chapuli, R.; Medina, M.A.; Quesada, A.R. Study of puupehenone and related compounds as inhibitors of angiogenesis. Int. J. Cancer 2004, 110, 31-38.

92. Pina, I.; Sanders, M.L.; Crews, P. Puupehenones congeners from an Indo-pacific Hyrtios sponge. J. Nat. Prod. 2003, 66, 2-6.

93. Killday, K.B.; Wright, A.E. Bis(Sulfato)-Cyclosiphonodictyol A, a new disulfated sesquiterpenehydroquinone from a deep water collection of the marine sponge Siphonodictyon coralliphagum. J. Nat. Prod. 1995, 58, 958-960.

94. Swersey, J.C.; Barrows, L.R.; Ireland, C.M. Mamanuthaquinone: An antimicrobial and cytotoxic metabolite of Fasciospongia sp. Tetrahedron Lett. 1991, 32, 6687-6690.

95. Blackburn, C.L.; Hopmann, C.; Sakowicz, R.; Berdelis, M.S.; Goldstein, L.S.B.; Faulkner, D.J. Adociasulfates 1-6, inhibitors of kinesin motor proteins from the sponge Haliclona (aka Adocia) sp. J. Org. Chem. 1999, 64, 5565-5570.

96. Bourghet-Kondracki, M.-L.; Martin, M.-T.; Guyot, M. Smenoqualone a novel sesquiterpenoid from the marine sponge Smenospongia sp. Tetrahedron Lett. 1992, 33, 8079-8080.

97. Wright, A.E.; Rueth, S.A.; Cross, S.S. An antiviral sesquiterpene hydroquinone from the marine sponge Strongylophora hartmani. J. Nat. Prod. 1991, 54, 1108-1111.

98. Guzmán, F.S.; Copp, B.R.; Mayne, C.L.; Concepcion, G.P.; Mangalindan, G.C.; Barrows, L.R.; Ireland, C.M. Bolinaquinone: A novel cytotoxic sesquiterpene hydroquinone from Philippine Dysidea sponge. J. Org. Chem. 1998, 63, 8042-8044.

99. Li, Y.; Zhang, Y.; Shen, X.; Guo, Y.-W. A novel sesquiterpene quinine from Haian sponge Dysidea villosa. Bioorg. Med. Chem. Lett. 2009, 19, 390-392.

100. Giannini, C.; Debitus, C.; Lucas, R.; Ubeda, A.; Paya, M.; Hooper, J.N.; D’Auria, M.V. New sesquiterpene derivatives from sponge Dysidea species with a selective inhibitor profile against hyman phosfopholipase A2 and other leukocyte functions. J. Nat. Prod. 2001, 64, 612-615.

101. Alvi, K.A.; Rodríguez, J.; Diaz, M.C.; Moretti, R.; Lee, R.H.; Slate, D.L.; Crews, P. Protein tyrosine kinase inhibitory properties of planar polycyclics obtained from the marine sponge Xestospongia cf. carbonaria and from total synthesis. J. Org. Chem. 1993, 58, 4871-4880.

102. Casapullo, A.; Minale, L.; Zollo, F. Paniceins and related sesquiterpenoids from the Mediterranean sponge Reniera fulva. J. Nat. Prod. 1993, 56, 527-533.

103. Zubia, E.; Ortega, M.J.; Carballo, J.L.; Salva, J. Sesquiterpene hydroquinone from the sponge Reniera mucosa. Tetrahedron 1994, 50, 8153-8160.

104. Rodriguez, A.D.; Yoshida, W.Y.; Scheuer, P.J. Popolohuanone A and B. Two new sesquiterpenoid aminoquinones from Pacific sponge Dysidea sp. Tetrahedron 1990, 46, 8025-8030. 
105. Carney, J.R.; Scheuer, P.J. Popolohuanone E, a topoisomerase II inhibitor eith selective lung citotoxicity from Pohnpei sponge Dysidea sp. Tetrahedron Lett. 1993, 34, 3727-3730.

106. Munday, R.H.; Denton, R.M.; Anderson, J.C. Asymmetric synthesis of 6'-hydroxyarenarol: The proposed biosynthetic precursor to popolohuanone E. J. Org. Chem. 2008, 73, 8033-8038.

107. Yong, K.W.L.; Jankam, A.; Hooper, J.N.A.; Suksamrarn, A.; Garson, M.J. Stereochemical evaluation of sesquiterpene quinones from two sponges of the genus Dactylospongia and the implication for enantioselective processes in marine terpene biosynthesis. Tetrahedron 2008, 64, 6341-6348.

108. Prokof'eva, N.G.; Utkina, N.K.; Chaikina, E.L.; Makarchenko, A.E. Biological activities of marine sesquiterpenoid quinones: Structure-activity relationships in cytotoxic and hemolytic assays. Comp. Biochem. Physiol. B: Biochem. Mol. Biol. 2004, 139, 169-173.

109. Schirmer, R.H.; Müller, J.G.; Krauth-Siegel, R.L. Disulfide-Reductase Inhibitors as Chemotherapeutic Agents: The Design of Drugs for Trypanosomiasis and Malaria. Angew. Chem. Int. Ed. Engl. 1995, 34, 141-154.

110. Monks, T.J.; Hanzlik, R.P.; Cohen, G.M.; Ross, D.; Graham, D.G. Quinone chemistry and toxicity. Toxicol. Appl. Pharmacol. 1992, 112, 2-16.

111. O’Brien, P.J. Molecular mechanisms of quinone cytotoxicity. Chem. Biol. Interact. 1991, 80, 1-41.

112. Schröder, H.C.; Wenger, R.; Gerner, H.; Reuter, P.; Kuchino, Y.; Müller, W.E.G. Suppression of the Modulatory Effects of the Antileukemic and Anti-Human Immunodeficiency Virus Compound Avarol on Gene Expression by Tryptophan. Cancer Res. 1989, 49, 2069-2076.

113. Sladić, D.; Gašić, M.J. Effects of iron(II) compounds on the amount of DNA damage in Friend erythroleukemia cells induced by avarol. Role of hydroxyl radicals. J. Serb. Chem. Soc. 1994, 59, 915-920.

114. Novaković, I.; Vujčić, Z.; Božić, T.; Božić, N.; Milosavić, N.; Sladić, D. Chemical modification of $\beta$-lactoglobulin by quinones. J. Serb. Chem. Soc. 2003, 68, 243-248.

115. Sladić, D.; Novaković, I.; Vujčić, Z.; Božić, T.; Božić, N.; Milić, D.; Šolaja, B.; Gašić, M.J.; Protein covalent modification by biologically active quinones. J. Serb. Chem. Soc. 2004, 69, 901-907.

Samples Availability: Available from the authors.

(C) 2010 by the authors; licensee MDPI, Basel, Switzerland. This article is an open access article distributed under the terms and conditions of the Creative Commons Attribution license (http://creativecommons.org/licenses/by/3.0/). 